УДК 347.91/.95 (477)

DOI https://doi.org/10.32837/yuv.v0i3.2186 D

\author{
Л. Діденко, \\ доктор юридичних наук, доцент, \\ професор кафедри цивільного та господарського права і процесу \\ Міжнародного гуманітарного університету
}

\title{
СУБ'ЄКТИ ЯК ЕЛЕМЕНТ ЦИВІЛЬНИХ ПРОЦЕСУАЛЬНИХ ПРАВОВІДНОСИН
}

Цивільні процесуальні правовідносини є явищем суспільним, тобто виникають та існують у безперервному зв'язку із суспільством у разі необхідності захисту чи охорони прав та інтересів одних членів суспільства від впливу інших.

На думку Ю.С. Червоного, цивільні процесуальні правовідносини - це врегульовані нормами цивільного процесуального права суспільні відносини, що виникають між судом, особами, які беруть участь у справі, та іншими учасниками цивільного процесу у зв'язку з їхньою діяльністю із забезпечення правосуддя у цивільних справах, у справах наказного та окремого провадження [9, с. 63]. Аналізуючи таку позицію, звернемо увагу на іiі такі особливості: 1) цивільні процесуальні правовідносини визначено як суспільні відносини, врегульовані нормами цивільного процесуального права; 2) дослідником встановлено в дефініції суб'єктний склад цивільно-процесуальних відносин, який, відзначимо, відповідає раніше встановленій нами в цій роботі структурі - суд, особи, які беруть участь у справі, інші учасники цивільного процесу; 3) мета цивільно-процесуальних відносин визначена у формі забезпечення правосуддя; 4) окрім того, автором перераховано види проваджень, характерних для цивільного процесу. Загалом, відзначимо, що такий підхід $€$ доречним, і рівень розкриття сутності цивільно-процесуальних правовідносин визначимо як високий.
Натепер можна виділити багато науковців, чиї наукові теорії стосовно суб'єкта правовідносин мають велике значення для правової доктрини нашої держави. Серед них виділимо таких як: О.М. Бандурка, I.О. Безлюдько, С.С. Бичкова, Ю.В. Білоусов, О.С. Захарова, О.М. Єфімов, Т.М. Кілічава, В.В. Комаров, М.П. Курило, А.Л. Паскар, Ю.Ю. Рябченко, О.Ф. Скакун, В.В. Сухонос, В.I. Тертишников, С.Я. Фурса, В.Д. Чернадчук, С.I. Чорнооченко, М.С. Шакарян, М.Й Штефан, В.С. Щербина, М.М. Ясинок тощо.

Коло суб'єктів цивільних процесуальних правовідносин $є$ надзвичайно широким, адже ними можуть бути будь-які учасники судочинства в конкретній цивільній справі, яка виникає у разі необхідності захисту або охорони прав чи інтересів одних членів суспільства від впливу інших, а також спеціальний суб'єкт таких правовідносин - суд, на який покладено функції такого захисту чи охорони прав та інтересів осіб. При цьому успішність виконання судом завдань цивільного судочинства зумовлюється належним встановленням кола учасників цивільного процесу та їх процесуального становища, адже правовий статус кожного із них у правових відносинах відрізняється.

Питання суб'єкта як елемента правових відносин, у тому числі й цивільних процесуальних, не викликає значних суперечок серед вітчизняних науковців, адже воно нині $€$ належ- 
ним чином врегульованими у нормах чинного ЦПК України [1]. При цьому варто враховувати, що кількісний та елементний склад цивільних процесуальних правовідносин не $€$ незмінним та стабільним, а безпосередньо залежить від обставин справи, предмета спору, виду провадження, стадії цивільного процесу, різновидів процесуальної діяльності, яка реалізовується під час процесу, тощо.

Цивільне процесуальне законодавство натепер чітко у змісті окремих статей виділяє суб'єктів цивільного процесу та вказує на їх суб'єктивні цивільні процесуальні права й обов'язки, проте об'єктом комплексних досліджень у такому контексті у вітчизняній правовій науці переважно виступає суд i меншою мірою - інші суб'єкти цивільно-процесуальних відносин.

Суб'єкт цивільного процесуального права - універсальна правова форма особи (фізичної та юридичної), яка з огляду на свою специфіку $€$ носієм усіх своїх суб'єктивних прав та обов'язків, закріплених у правових нормах (об'єктивному праві) у сфері цивільного процесуального права.

Суб’єкт цивільних процесуальних правовідносин - це не тільки універсальна, а й унікальна і специфічна правова форма реалізації особами (суб'єктами права) своїх прав і обов'язків у певному цивільному процесуальному правовідношенні, що отримує своє втілення у визначеному в законі особливому правовому положенні (суд, сторони, представник, інші учасники судового процесу).

Слід погодитись із В.Н. Щегловим, на думку якого «суб'єкт цивільного процесуального права стає суб'єктом цивільно-процесуальних відносин із вчиненням юридичного факту» $\mathrm{i}$ що «бути суб'єктом правовідносин - значить брати участь у процесі у конкретній цивільній справі, володіти процесуальними правами і нести процесуальні обов'язки». Проте з уточненням щодо володіння лише тими процесуальними правами і процесуальними обов'язками, які закон надає відповідному учаснику процесу [11, с. 128].

У навчальному посібнику за редакцією Ю.В. Білоусова суб'єкт цивільних процесуальних правовідносин роз'яснюється просто як носій цивільних процесуальних прав та обов'язків [2, с. 22]. При цьому поділ суб'єктів цивільних процесуальних правовідносин здійснено на дві групи: суд та учасники цивільного процесу, які своєю чергою поділяються на осіб, які беруть участь у справі, та інших учасників процесу, згідно із нормами чинного на момент написання посібника Цивільного процесуального кодексу України. Інші наявні у сучасній теорії цивільного процесуального права позиції не $є$ набагато досконалішими за представлену вище. Зокрема, O.O. Штефан визначає суб'єктів цивільних процесуальних правовідносин як носіїв цивільних процесуальних прав і обов'язків у процесі здійснення правосуддя в цивільних справах, цивільному судочинстві [10, с. 17]. Тобто суб'єкти цивільних процесуальних правовідносин розглядаються аналогічним чином, втім робиться уточнення про те, що процесуальні права й обов'язки реалізовуються саме у цивільних справах, цивільному судочинстві. Інша концепція полягає в роз'ясненні сутності суб'єктів цивільних процесуальних правовідносин як їх учасників.

Наприклад, колектив авторів підручника «Цивільний процес України» за редакцією В.О. Кучера дав визначення суб'єктів цивільних процесуальних правовідносин як учасників процесуальних відносин, які виникають у суді з приводу розгляду і вирішення цивільних справ [5, с. 75].

У такому контексті найбільш вдалою вважаємо позицію А.Л. Паскар, яка вже раніше наводилась нами у цій роботі. Згідно із нею, суб'єкти цивільно-процесуальних правовідносин це органи і особи, які через норми 
цивільного процесуального законодавства наділяються суб'єктивними цивільними процесуальними правами та обов'язками, у разі порушення яких притягуються до передбаченої законом відповідальності, беруть участь у розгляді і вирішенні цивільних справ з метою захисту порушених або оспорюваних, невизнаних прав, свобод чи інтересів фізичних осіб, прав та інтересів юридичних осіб, інтересів держави [6, с. 334]. Відзначаємо саме цю позицію із таких причин: 1) визначається, що суб'єктами цивільних процесуальних правовідносин можуть бути і фізичні особи, і органи; 2) встановлено, що цивільні процесуальні права та обов'язки суб'єктів мають суб'єктивний характер, тобто кожному суб'єкту належить конкретно визначений специфічний обсяг прав та обов'язків; 3) визначено мету участі суб'єктів у розгляді і вирішенні цивільних справ, якою $є$ захист невизнаних прав, свобод чи інтересів.

Тож зробимо висновок, що поняття суб'єктів цивільних процесуальних правовідносин у вітчизняній науковій літературі тлумачиться просто та однотипно. Натепер у цьому питанні вітчизняні науковці загалом досягли згоди, і поняття суб'єктів цивільних процесуальних правовідносин прийнято розглядати у таких розрізах:

1) суб'єктами цивільних процесуальних правовідносин $€$ учасники процесуальних відносин, які виникають у суді з приводу розгляду і вирішення цивільних справ;

2) суб'єктами цивільних процесуальних правовідносин $€$ носії цивільних процесуальних прав та обов'язків у процесі здійснення правосуддя в цивільних справах, цивільному судочинстві, до яких належать суд та учасники цивільного процесу, які своєю чергою поділяються на осіб, які беруть участь у справі, та інших учасників процесу;

3) суб'єкти цивільних процесуальних правовідносин - це особи, які здійснюють правосуддя у цивільних справах, особи, які беруть участь у справі, та особи, які не беруть участі у справі;

4) суб'єктами цивільних процесуальних правовідносин $€$ носії цивільних процесуальних прав та обов'язків, до яких встановлено особливі вимоги щодо цивільної процесуальної правоздатності та дієздатності.

Виходячи із наведених концепцій визначення поняття суб'єктів цивільних процесуальних правовідносин, загальними ознаками суб'єктів цивільно-процесуальних відносин є:

1) іх індивідуальний, колективний або державний характер;

2) активна роль у процесі здійснення правосуддя в цивільних справах, цивільному судочинстві;

3) специфічний характер цивільної процесуальної правосуб'єктності таких осіб.

Цивільні процесуальні правовідносини відзначаються певними особливостями (ознаками), які $€$ характерними саме для цієї групи правовідносин. Для процесуальних правовідносин такою ознакою є особливий суб'єктний склад - суд і учасники процесу. Ця ознака відрізняє процесуальні правовідносини від будь-яких інших як матеріальних, так і процесуальних правовідносин.

Особливість цивільних процесуальних правовідносин проявляється в тому, що зв'язки процесуального характеру виникають не між учасниками судової справи, а між судом і учасником справи, причому 3 кожним індивідуально [4, с. 46].

В юридичній літературі набула поширення категорія «учасник» щодо судового процесу [8]. Зокрема, у гл. 4 ЦПК України подано поняття «учасники судового процесу». Порівнюючи поняття суб'єкта та учасника, О.В. Бачун у контексті вивчення проблеми правового статусу суб'єктів адміністративного судочинства, вказує на більш широкий характер категорії «суб'єкт» порівняно із кате- 
горією «учасник». Так, до категорії «суб'єкт» він відносить, крім власне учасників (сторін, третіх осіб, їх представників тощо), також суд [6].

Справді,

ЦПК України у ст. 42 чітко встановлює, що учасниками справи є сторони, треті особи (у справах позовного провадження), заявник та боржник (у наказному провадженні), в окремому провадженні учасниками є заявники, інші заінтересовані особи тощо (також у ст. 52 ЦПК України говориться про участь третіх осіб у судовому процесі, у ст. 58 ЦПК України - про участь представника у судовому процесі, ст. 65 ЦПК України - про інших учасників судового процесу). Таким чином, законодавець закріплює, що склад та перелік учасників судового процесу можуть бути різні залежно від виду судового провадження [1]. Але суд $є$ основним і обов'язковим суб'єктом цивільних процесуальних правовідносин, оскільки незалежно від присутності інших учасників процесу суд $€$ наявним завжди та саме на нього покладено виконання основного завдання цивільного судочинства справедливий, неупереджений і своєчасний розгляд цивільних справ [7].

B.M. Тертишник вказує, що учасники процесу - це особи: а) чия участь у справі передбачена процесуальним законодавством, при тому, що відсутні обставини, за яких закон виключає можливість ї участі у процесі; б) вони мають певні права та обов'язки (закон визначає порядок їхньоі реалізаціі); в) діють у судочинстві відповідно до своїх обов'язків та прав у встановленому порядку; г) вступають у процесуальні правовідносини; г) несуть відповідальність за невиконання своїх обов'язків або порушення прав інших. Але ми не зовсім згодні з п. г) вказаної класифікації, тому що вважаємо, що категорія процесу є більш вузькою порівняно з процесуальними правовідносинами та входить до цієї категорії структурно.
Учасники цивільних процесуальних правовідносин набувають процесуальні права і обов'язки за наявності комплексу обставин, без яких вони не відбуваються [3, с. 50].

Правосуб'єктність суб'єктів, які здійснюють правосуддя в цивільних справах, безпосередньо пов'язана із тим, що суд є обов'язковим суб'єктом цивільних процесуальних правовідносин. Відповідно, весь обсяг його прав та обов'язків є таким, який не притаманний жодному іншому суб'єкту цивільних процесуальних правовідносин. Загалом, обсяг та характер повноважень суду, як обов'язкового суб'єкта цивільних процесуальних правовідносин, потребує окремого комплексного дослідження. Втім, виходячи із положень чинного законодавства, визначимо особливості правового статусу суб'єктів, які здійснюють правосуддя у цивільних справах таким чином:

1) суд, вступаючи у цивільні процесуальні правовідносини, зобов'язаний зберігати безсторонність та об'єктивність;

2) у разі, якщо є сумніви у безсторонності та об'єктивності суду, в чинному цивільному процесуальному законодавстві передбачено інститут відводу (самовідводу) суддів;

3) відповідна судова інстанція може бути суб'єктом виключно тих правовідносин, які відповідають підсудності та інстанційній юрисдикції;

4) основним призначенням суду як суб’єкта цивільних процесуальних правовідносин $є$ реалізація його виключної компетенції у разі здійснення правосуддя у цивільних справах;

5) не допускається делегування прав, обов'язків та функцій судів іншим групам суб'єктів цивільних процесуальних правовідносин, а також привласнення цих прав, обов'язків та функцій іншими суб'єктами цивільних процесуальних правовідносин;

6) ЦПК України визначено, що у цивільних процесуальних право- 
відносинах від імені суду виступає суддя, який одноособово розглядає цивільну справу або у складі колегіі суддів [1].

Іншими учасниками судового процесу є помічник судді, секретар судового засідання, судовий розпорядник, свідок, експерт, експерт з питань права, перекладач, спеціаліст. На відміну від суб'єктів, які здійснюють правосуддя в цивільних справах, а також інших учасників судового процесу, учасники справи наділені юридичною заінтересованістю. Тож їхній правовий статус у розгляді та вирішенні цивільної справи визначається саме іiі наявністю.

У статті 2 ЦК України визначено, що учасниками цивільних відносин $є$ фізичні особи та юридичні особи, у тому числі держава Україна, Автономна Республіка Крим, територіальні громади, іноземні держави та інші суб'єкти публічного права. Такі суб'єкти наділяються цивільною процесуальною правоздатністю 3 моменту народження (виникнення, утворення, заснування тощо) та втрачають іï у зв'язку зі смертю (ліквідацією, реорганізацією тощо). Таким чином, особливостями цивільних процесуальних прав і обов'язків суб'єктів, які $€$ учасниками справи, та суб'єктів, які є іншими учасниками судового процесу, є:

1) права та обов'язки варто поділити на загальні та спеціальні;

2) загальні права та обов'язки учасників цивільних процесуальних правовідносин $є$ характерними для всіх без винятку суб'єктів, є учасниками справи та суб'єктів, які $€$ іншими учасниками судового процесу;

3) спеціальні права та обов'язки учасників цивільних процесуальних правовідносин залежать від процесуального статусу суб'єкта у процесі.

Отже, дослідження поняття та ознак суб'єктів цивільно-процесуальних відносин, їх правового статусу засвідчило їх специфічний характер, наявність теоретичних проблем, а також комплексний та масштабний характер такого інституту.

Стосовно правового статусу суб'єктів цивільно-процесуальних відносин у процесі дослідження ми звернули увагу на те, що його по суті варто розглядати у двох аспектах: як загальний та спеціальний правовий статус суб'єктів цивільно-процесуальних відносин. Загальний характеризує участь усіх суб'єктів у цивільному процесі, відштовхуючись від особливостей цивільного судочинства. Спеціальний правовий статус суб'єктів цивільно-процесуальних правовідносин розкриває роль кожного суб'єкта у цивільних процесуальних правовідносинах.

У статті визначено, шо цивільне процесуальне законодавство натепер чітко у змісті окремих статей виділяє суб'єктів цивільного процесу та вказує на ї суб'єктивні цивільні процесуальні права і обов'язки. Проте об'єктом комплексних досліджень у такому контексті у вітчизняній правовій науці переважно виступає суд і меншою мірою - інші суб'єкти цивільно-процесуальних відносин.

У статті підкреслено, що дослідження суб'єкта циивільних процесуальних правовідносин усе ще не втрачає своєї актуальності, адже з огляду на масштабний елементний склад такого інституту, його складники нині отримали замало наукової уваги та аналізу. Тобто, незважаючи на встановлене загальноприйняте розуміння того, хто може бути суб'єктом цивільних процесуальних правовідносин, дослідження їх різновидів натепер перебувають на незадовільному рівні.

Зазначено, що зміст та сутність категорії суб'єктів у кожній окремій справі відрізняється, а отже, питання поняття та ознак суб'єктів цивільних процесуальних правовідносин, їх класифікації та правового статусу потребують повноцінного комплексного дослідження. 
У статті обтрунтовано, що дослідження суб'єктів цивільних процесуальних правовідносин у вітчизняній науиі здійснюються регулярно, втім більшість праць мають досить поверхневий характер $i$, як наслідок, питання, пов'язані з учасниками цивільного процесу, в основному розглядаються у контексті норм чинного Цивільного процесуального кодексу України від 18 березня 2004 року № 1618-IV.

Визначено склад суб'єктів права $і$ правовідносин, що дозволяє, зокрема, розмежувати суміжні галузі права, вирішити питання про сферу регулювання, про те, чи є суб'єктами процесуального права інші юрисдикційні органи, крім суду. Вивчення питання про суб’єктів цивільного процесуального права має теоретичне $і$ практичне значення, оскільки значною мірою цивільно-прочесуальний метод регулювання суспільних відносин характеризується правовим становищем суб'єктів, засобами впливу на їх поведінку, ї правами та обов'язками. Зазначено, що суб'єктами циивільних процесуальних правовідносин є суд, індивідуальні й колективні суб'єкти права, держава та ї структурні одиниці, а також соціальні спільноти, яким належить активна роль у проиесі иивільного судочинства, які виступають реалізаторами специфічних юридичних властивостей - суб'єктивних юридичних прав $і$ обов'язків, повноважень, що знаходять свою реалізацію у вступі у цивільне процесуальне правовідношення та використанні в них своєї правосуб'єктності.

Ключові слова: суд, склад, суб'єкт, громадяни, класифікація, учасники, повноваження, заінтересовані особи, юридична відповідальність, права та обов'язки, посадові особи, цивільні процесуальні правовідносини, цивільне процесуальне законодавство.
Didenko L. THE SUBJECT AS AN ELEMENT OF CIVIL PROCEDURAL LEGAL RELATIONS

The article stipulates that the civil procedural legislation today clearly distinguishes the subjects of civil proceedings in the content of certain articles and indicates their subjective civil procedural rights and responsibilities. However, the object of complex research in this context in the domestic legal science is mainly the court, and to a lesser extent other subjects of civil procedure.

It is emphasized that the study of the subject of civil procedural legal relations still does not lose its relevance, because given the largescale elemental composition of this institution, its components have received little scientific attention and analysis. That is, despite the established common understanding of who may be the subject of civil procedural legal relations, research on their varieties is currently at an unsatisfactory level.

It is notes that the content and essence of the category of subjects in each case differs, and therefore the concept and characteristics of the subjects of civil procedural legal relations, their classification and legal status require a full comprehensive study.

The article substantiates that studies of subjects of civil procedural legal relations in domestic science are carried out regularly, but the vast majority of works are quite superficial, and as a consequence issues related to civil proceedings are mainly considered in the context of the current Civil Procedure Code of Ukraine of March 18, 2004 No. 1618-IV.

The composition of subjects of law and legal relations is determined, which allows, in particular, to distinguish related branches of law, to decide on the scope of regulation, on whether the subjects of procedural 
law are other jurisdictions other than the court. The study of the subject of subjects of civil procedural law has theoretical and practical significance, as to a large extent the civil procedure method of regulating public relations is characterized by the legal status of subjects, means of influencing their behavior, their rights and responsibilities. It is noted that the subjects of civil procedural legal relations are the court, individual and collective subjects of law, the state and its structural units, as well as social communities, which have an active role in civil proceedings, and which act as implementers of specific legal properties - subjective legal rights and obligations, powers, which are realized in the entry into civil procedural legal relations and the use of their legal personality.

Key words: court, composition, subject, citizens, classification, participants, powers, interested persons, legal responsibility, rights and obligations, officials, civil procedural legal relations, civil procedural legislation.

\section{Література}

1. Цивільний

процесуальний кодекс України : Закон України від 18.03.2004 № 1618-IV. Відомості Верховної Ради України. 2004. № 40-41, 42. C. 492

2. Андрушко А.В. Цивільний процес : навчальний посібник. / А.В. Андрушко, Ю.В. Білоусов, P.О. Стефанчук, О.I. Угриновська та ін. ; за ред. Ю.В. Білоусова. Київ : Преиедент, 2005. 172 с.
3. Діденко Л.В. Особливості змісту цивільних процесуальних правовідносин. Юридичний науковий електронний журнал. 2016. № 3. С. 49-51.

4. Єпанчінцев О.С. Поняття та склад суб'єктів цивільних процесуальних правовідносин. Актуальні проблеми вітчизняної юриспруденції. 2018. № 4. C. $45-48$.

5. Цивільний процес України : підручник / В.О. Кучер та ін. ; ред. В.О. Кучер. Львів : ЛьвДУВС, 2016. 768 с.

6. Кілічава Т.м. Цивільне процесуальне право : навчальний посібник. Київ : Центр учбової літератури. 2007. 352 c.

7. Колісник О.В. Суд як суб'єкт цивільних процесуальних правовідносин: дис. канд. юрид. наук: 12.00.03. Харків, 2008. 224 C.

8. Рябченко Ю.Ю. Суб’єкт цивільного процесуального права у сучасній парадигмі права: дисертація на здобуття наукового ступеня доктора юридиних наук. Харків, 2018.

9. Червоний Ю.С. Цивільний процес України : підручник / За ред. Червоного Ю.С. Київ : Істина, 2007. 392 с. (рішенням Вченої Ради ОНЮА та науково-методичної комісії МОН України посібнику надано гриф Міністерства освіти та науки України).

10. Штефан О.О. Цивільне процесуальне право України : навчальний посібник. Київ : Юрінком Інтер, 2009. $360 \mathrm{c}$.

11. Щеглов В.Н. Гражданское проиессуальное правоотношение. Москва: Юрид. лит., 1966. 167 с.

12. Ясинок М.М. Теоретичні проблеми цивільного процесуального права : підручник / М.М. Ясинок, М.П. Курило, O.В. Кіріяк, О.О. Кармаза, С.I. Запара ma ін. ; за заг. ред. Ә.ю.н. професора М.м. Ясинка. Київ : Алерта, 2016. 890 c. 